\title{
Factors of Successful Women Leadership in Saudi Arabia
}

\author{
Manal Matouq Kattan ${ }^{1}$, Carmen de Pablos Heredero ${ }^{1}$, Jose Luis Montes Botella ${ }^{1} \&$ Vasilica Maria Margalina ${ }^{1}$ \\ ${ }^{1}$ Rey Juan Carlos University, Madrid, Spain, Social Sciences Faculty, Madrid, Spain \\ Correspondence: Manal Matouq Kattan, Social Sciences Faculty, Rey Juan Carlos University, Paseo de los \\ Artilleros s/n, 28032, Madrid, Spain. Tel: 346-4800-8874/96-65-9091-1116. E-mail: kattan_manal@yahoo.com
}

\author{
Received: December 26, 2015 Accepted: January 28, 2016 Online Published: April 19, 2016 \\ doi:10.5539/ass.v12n5p94 \\ URL: http://dx.doi.org/10.5539/ass.v12n5p94
}

\begin{abstract}
Saudi woman encounters many shapes of sexual segregation that stand as an obstacle against her option to occupy a frontline leadership position. There are misconceptions in our society that women are not even suitable for leadership. This paper aims to highlight the factors promoting success in leading organizations in general and the success of women in particular with highlighting the status of Saudi women in these factors. The main hypothesis is "the more the woman has factors of leadership, the more success she may achieve in leading organizations". A model including the factors promoting successful Saudi Women Leaders is proposed and discussed to ensure accuracy of the above mentioned hypothesis. The findings expect bright future for Saudi women in light of keenness of King Abdullah to support woman to play her role in the society and preserve the rights to demonstrate her success in leadership.
\end{abstract}

Keywords: Saudi, women, leadership, success, factors

\section{Introduction}

Due to various cultural and structural characteristics of Saudi society, women in leadership positions in many Saudi organizations encounter different reality when compared with their male counterparts. The traditions and Islamic instructions prevailed in Saudi Arabia restricted the social role of women in this country and similar preserving societies. Women are not welcomed in public places and have to be at home most of the time. Despite the progress and opportunities offered to Saudi women in term of health protection and education, still limited opportunities are available for female entrepreneurs to break in especially in political and economic aspects due to unique social norms (Ahmad, 2011). In Saudi society; Saudi women suffer from multiple forms of discrimination due to factors which rooted in traditional Saudi culture and social structure.

In the light of the contemporary developments that play an essential and vital role in any successful organization, availability of several factors, capabilities and behaviors are required in the leader to enhance and magnify his chances of success in a leading position. In this study, these factors have been identified and its effects upon women leadership success have been analyzed in the Saudi society.

\section{Factors Affecting Women Leadership}

\subsection{Culture}

Any organization is influenced by two types of culture, the internal culture that spreads among its employees which covers the psychology, attitudes, experiences, beliefs and values, and the external culture which represents forces coming from outside the organization, although out of its control, it may nonetheless affect organizational performance. Organizational and social culture are thus the two main forms of culture which have been identified as factors that determine the success rate of leadership in an organization.

\subsubsection{Organizational Culture}

Webster (1989) describes organizational culture as the fundamental shared set of beliefs and values that put customer in the center of the firm's thinking on strategy and operations. Ravasi and Schultz (2006) affirms that organizational culture is a set of shared mental assumptions that guide interpretation and action in organizations by defining appropriate behavior for various situations. Despite our agreement with the above mentioned definitions, culture takes long time to shape, and learning processes may affect the culture but they may not have any contribution in its shape. Therefore, the perspective of organizational culture will be considered as "the values, attitudes, experiences, beliefs shared by staff in the organization, most of them influenced by the society" 
(Webster, 1989).

\subsubsection{Social Culture}

In general the region of the Arab peninsula is characterized by gender inequality (Moghadam, 2003). This main obstacle creates difficulties in respect of women's rights and liberties as reflected in some laws. In Saudi Arabia women however still fight for their rights. The country is characterized by gender inequality, and the clearest reflection of this is the fact that all women, regardless of age, are required to have a male guardian (Asmaa, 2010). In 2009, the World Economic Forum Global Gender Gap Report ranked Saudi Arabia 130 out of 134 countries for gender parity (Gender Gap Report, 2009).

There are a number of reasons that explain the gender inequality and lack of leadership roles for women in Saudi society. First, women could not reach leadership positions if the culture did not allow that, or they face many obstacles that have negative impacts on women reaching leadership positions. Second, women leaders face many difficulties to lead employees especially men successfully if they show negative values against women, who do not fully co-operate with her in achieving the organization's goals, and may in contrast seek to make the woman fail to take decisions in order to prove that man is better than woman in leading the organization.

Despite the above observations, many changes have been witnessed in Saudi society and culture in respect of woman, especially as now it is acceptable to see women working as a tellers, lawyers, waitresses, saleswomen, and holding other jobs, more than before. Also female athletes competed in the Olympics in 2012 in London, England for the first time. According to Idris (2007), societal changes that accompanied modernization also brought change to traditional and religious institutions (Ecklund, 2006), whereas the Kingdom witnesses in the era of the Custodian of the Two Holy Mosques; King Abdullah bin Abdulaziz AlSaud great renaissance for women as he facilitates taking charge of high positions to them such as Minister of Education, and many other high positions. He allows women to participate in Saudi parliament (Majlis AlShowra) and to elect municipal councils (Okaz, 2011).

Despite the above advances, the empowerment of women in Saudi Arabia still has a long way to go. Progressive women who advocate modernity are still a minority. The conservatives still support gender segregation policies (Fatany, 2013), and still religion and society combine to foster significant social control, and there is still strict gender segregation sanctioned by the state and society but in lesser degree than before.

\subsection{Education}

Education in the general sense is any act or experience that has a formative effect on the mind, character, or physical ability of an individual. It can be defined as the act or process of acquiring knowledge during childhood and adolescence (Heritage ${ }^{\circledR}$ Dictionary, 2000). An educated person that has access to optimal states of mind makes him/her able to perceive accurately, think clearly and act effectively to achieve self-selected goals and aspirations (Berg et al., 2011). No doubt that education contributes to personal and economic well-being, and creates knowledge base which leads to qualifications that may benefit in developing works (Australia Bureau of Statistics, 2006).

According to the OECD (2014) Women in Business Report in the Middle East and North Africa Region (Mena), literacy rate reaches $100 \%$ among women of 15-24 years old in the Gulf countries, Jordan, Syria and Tunisia, while this rate decreases up to $70-75 \%$ in Egypt, Morocco and Yemen. The rate of tertiary -level education is uneven in some MENA countries. While it represents more than 50\% of women between the age of 15-24 years in Lebanon and Libya, it is only 10\% in the rest of MENA countries (OECD, 2014, p. 60).

Education is at the forefront of the Saudi Government's priorities along times. As government considers it the bedrock for the progress of nations, the education sector has witnessed important developments since the founding of the first Ministry of Education. Thousands of elementary, intermediate and secondary schools have been established, in addition to colleges, higher institutes and several universities.

The government provides free general and higher education (post-secondary), and financial help for male and female students in some areas of general education. University students receive financial help and free housing. In addition, meals, books, and transportation are offered at subsidized prices especially for female students who are provided with free transportation (Souad \& Al-Omari, 2007).

According to the last statistics of the Ministry of Education in the Kingdom of Saudi Arabia (he.moe.gov.sa 2015), a progress in student numbers in different phases of education has been produced. Statistics also show that there is remarkable increase of the number of females in all Saudi Universities as estimated in March 2015 compared to previous years. Meanwhile female in the recent years (2006-2007-2008-2009) ranged from 49-50\% of students, the last statistics conducted in 2015 indicated that the number of females is 42.0928 out of 66.9271 
which represents about $63 \%$ of the total regular or external students studying in the Saudi Universities.

In the past few decades, the Gulf Cooperation Council (GCC) admits that women have made enormous strides in their access to education especially in UAE and Saudi Arabia, as 60 percent and 70 percent, respectively, of university students are women, and GCC governments regularly sponsor women who want to study abroad and bring new talents and skills back to their burgeoning economies (Eagly, 2007).

Despite the improvement in the gender gap in education, this is not reflected in women's employment and entrepreneurship rates. Compared to men who represent $48 \%$ of employment rate, women represent only $17 \%$ and remain the lowest employment rate in the world. Concerning entrepreneurial activities the gap is also high. Only $12 \%$ of women are entrepreneurs compared to $31 \%$ of men in MENA region (OECD, 2014, p. 60).

No doubt that there is a strong link between getting higher education certificates and becoming a more effective leader. Westbrook (2009) proves that there is a relationship between educational qualifications of chief financial officers and effectiveness of local district financial leadership in Alabama Public Schools.

It is true that the more a person gets higher educational certificates, the more opportunity he gets to take leadership positions, and the more success he can achieve. Hence, academic degrees are important in order to gain high leadership occupations and to be more effective in those positions; this is why employers and policy makers value academic qualifications (Nissar, 2010).

It is recently noted that women have enrolled more than men in educational institutions whether preliminary, secondary or even high universities and they get better marks and achieve more percentage in average results than men in general. Women success in leadership is about making the most of their talents and abilities, and that requires dedication and study in academic institutions that will stretch their intellectually.

As mentioned above, women in Saudi Arabia achieve highest levels of enrollment in different educational levels than men. Girls represent now about $60 \%$ of students in educational institutions as a result of the government's effort to promote women's education, although they still represent only $14 \%$ of its labor force. Most of them work in education, $6 \%$ in public health, and $95 \%$ in the public sector (Miller, 2011). Women still face several obstacles to get leadership positions that match with their educational qualification (DeAnne et al., 2011), yet these qualifications they get, as female leaders are still less favorable than that of male ones in Saudi Arabia, even if they get higher educational qualifications more than men, as Cheung (2010) mentioned that the context of a culture affects gender expectations for women and men as men are still preferred.

\subsection{Society}

Anthropologists tend to classify different societies according to the degree to which different groups within a society have unequal access resources, prestige, or power. Societies over times developed cultures that support masculinity against feminism with help of economic factors rather than social factors that help to maintain this stereotype (Hofstede, 2001). Till now the perception of women as "outsiders" in work because of their physical differences still spreads especially in most of developing countries. The types of society shaped different views for women, and this has been reflected upon their participation in workforce, hence taking charge of leadership positions.

Thus, a woman who aspires to leadership positions must overcome both her childhood socialization, which discouraged development of some essential qualities, and a popular perception of the maleness of leadership both of which tangibly reduce the chance she will be judged qualified. In addition to socialization and stereotyping, other barriers to females' upward mobility into leadership positions include (Acker, 1992): (a) discrimination against them in personnel decisions involving promotion, selection, and supervision; (b) a dearth of women and men willing to mentor women; (c) management development opportunities that are based on job rotation.

The modernization, economic factors, technology factors and liberalization tendency help women to call for their rights, and establish many feminism movements that support women rights (Altintas, 2008). Globalization, information and communication revolution help those thoughts spread over the world, and have some influences, although women still not have the same leadership positions equal to their percentage in society, even in the United States and Western Countries (Calas, 1993).

After five decades of intense modernization, the Saudi Arabia's urban infrastructure was highly developed and technologically sophisticated. Now, globalization, modernization, revolution of information technology, satellites, internet, liberalization, feminism movements, world organization, outside pressure, with other internal factors such as women education, immigration to towns, society urbanization, foreign workers, Saudi development has effects of generation and help women placed in areas of public space. 
As Saudi women take jobs that were previously not open to them, they're creating a new workplace dynamic in the country. More Saudis now accept the idea of women working in jobs such as law or real estate (Abu-Nasr, 2013).

The World Economic Forum 2009 Global Gender Gap Report ranked Saudi Arabia as the only country to score a zero in the category of political empowerment. The report also noted that Saudi Arabia is one of the few Middle Eastern countries to improve from 2008, with small gains in economic opportunity (World Economic Forum Report, 2009). New York-based Human Rights Watch said in a December report that Saudi women are still treated as "legal minors, no matter how old they are" (Report, 2013). Saudi leader and officials acknowledge that change is coming but slowly especially in such a conservative society in order to avoid bad effects on the stability of the society.

Of course, women leadership in industrial societies will be lesser than in post-industrial societies, which provides equal opportunities of treatment to both women and men. Information societies which developed into knowledge societies provide women with important tools to lead organization effectively such as easy getting information and knowledge, and easy communications that facilitate work (Hughes, 2001). Evidence shows that school, society and media interventions can promote gender equality. Community interventions can address gender norms and attitudes through different communication means (Mario Peter, 2009). Media interventions can also contribute to alter gender norms and promote women's rights; Public awareness campaign and other interventions delivered by television, radio, newspapers and other media can be effective for altering attitudes towards gender equality norms (Mario Peter, 2009).

Furthermore, the national and international frameworks that promote gender equality are needed to be developed by laws or international conventions especially in societies with rigid gender roles (Koening, 2003). So any country makes law framework and joint the convention on the elimination of all forms of discrimination against women, the most comprehensive treaty on women's human rights, which came into force in 1981, has been ratified or acceded to by 165 states worldwide. That calls for equality between women and men in respect to civil, political, economic, social and cultural rights, emphasize the importance of equal participation of women with men in public life (Norris \&Inglehart, 2000), and the leadership of women is a sort of this equality.

\subsection{Skills}

Skill is an ability and capacity acquired through deliberate, systematic, and sustained effort to smoothly and adaptively carryout complex activities or job functions involving ideas (cognitive skills), things (technical skills), and/or people (interpersonal skills) (Dilts, 1996).

Good leadership requires attitudes and behaviors which characterize and relate with skills that people develop (Greenleaf, 1970), as many capabilities in life are a matter of acquiring skills and knowledge and then applying them in a reliable way. Good leaders are followed chiefly because people trust and respect them, rather than the skills they possess (Martín García \& de Pablos Heredero, 2014). To be an effective leader, one needs an exclusive set of human relations and interpersonal skills. Leadership essence is being able to influence. To influence one needs a number of component skills. Some are fairly easy to develop; others take a long time to be acquired.

There is a direct correlation between the implementation of shared leadership practice and product improvement, higher morale, and innovative problem solving, which leads to a more hospitable environment for instituting change to be better (Garcia Martínez \& De Pablos Heredero, 2014).

As good leadership depends on attitudinal qualities, not only management processes, some authors show us examples of highly significant leadership qualities and skills such as: integrity, honesty, humility, courage, commitment, sincerity, passion, confidence, positivity, wisdom, determination, compassion, sensitivity, intelligence, adjustment, extraversion, conscientiousness, openness to experience and general self-efficacy (Vader \& Alliger, 1986; Kickul, 2000; Judge, 2002; Rotundo \& McGue, 2006). Rather than many qualities of effective leadership, like confidence and charisma, continue to grow from experience in the leadership role and be skilled by training such as cognitive abilities, motives, values, social skills, expertise, and problem-solving skills. Integrations of multiple attributes distinguish between those leader attributes that are generally not malleable over time and those that are shaped by, and bound to, situational influences how stable leader attributes account for the behavioral diversity (Zaccaro, 2007).

In a study conducted by Berdahl \& Anderson (2005), it is found that men's preferences are more likely to be adopted by women because of their ability and motivation to perform such doing compared by men. Women are likely to be more motivated than men to learn and engage in other-sex norms because of sex differences in power 
(Berdahl \& Anderson, 2005).

When compared to men, women as general have a great fear from carrying out a business by themselves because of failure that prevent them to take the risk. Such behavior lowers the chance of motivation and rate of actual entrepreneurial activity among women and widens the gap with men as the gender gap in this respect in the MENA region is greater than any other region in the world (OECD, 2014).

Gender stereotyping can have consequences for women trying to climb the ladder in the working world, although men are still seen as typical leaders, leaving women with a hard road to the leadership positions. Sabattini (1999) said that women have to prove themselves to be qualified more frequently than men, so they must have skills more than men, as women face higher standards. Sabattini describes the three dilemmas facing women leaders:

-Extreme perceptions: if women leaders go against gender stereotypes, they are seen as too tough; however, if they go along with the stereotypes, they are depicted as too soft.

-High competence/lower rewards: women usually have to work harder than men for the same position in order to prove their abilities. Women tend to receive fewer rewards.

-Competent but disliked: women who act with assertiveness are seen as not personable, but those who are likable are depicted as lacking leadership skills. No matter how women behave, they are perceived in a certain way.

So, stereotyping issue is an organizational problem, not just an individual woman problem. Organizations are missing out on a great source of talent: women leaders, so that it has to give women leaders and other co-workers resources to spread the word about women leadership skills as well as the effects of gender stereotyping (Sabattini, 1999).

In 2005, a yearlong study conducted by Caliper (2005), identified a number of characteristics that distinguish women leaders from men. The Caliper study findings are summarized into four specific statements about women's leadership qualities:

- Women leaders are more persuasive than their male counterparts.

- When feeling the sting of rejection, women leaders learn from adversity and carry on with an "I'll show you" attitude.

- Women leaders demonstrate an inclusive, team building leadership style of problem solving and decision making.

- Women leaders are more likely to ignore rules and take risks than men (Lowen, 2011).

The government of Saudi Arabia seeks to support women leadership skills, so formal universities held many training programs and workshops to support their personal and leadership development. The programs aimed to provide a supportive group learning experience leaving participants with insight into their individual personality type and personal leadership style and understanding of high-performing teams, how organizations work, leadership principles, skills and influencing, networking and organizational change. The programs were part of the Universities contribution to the current government's efforts on improving women's leadership skills (Nestor, 2013).

A recent survey held by Leadership Foundation associate Glyn Jones in 2013, discovers that the Saudi women (according to the employers) are well-informed, tend to be more punctual and have better performance, dedicated to a high level work effort, very appreciative and determined to use their advanced degrees to develop themselves in the world of work and their lives outside the work. Saudi women are increasingly braving opprobrium to seek meaningful work, which is destined to challenge and perhaps ultimately undermine Saudi Arabia's "different, but equal" façade.

\subsection{Experience and Knowledge}

Experience and knowledge play an important role in women leadership success (Similes Dictionary, 1998). Hence, as more experiences women leaders have had at work, the more ability they have to accelerate their leadership skills and grant their success. The deepest knowledge women have, the highest ability to achieve the organizational goals effectively, a thing that will help them clearly think about their role and function in the organization and will support them in their success (Laddin, 2007).

By contrast, organizations that see the learning potential in experience strive to equip aspiring leaders to mine their experiences - continuously and intensively - for insight into what it takes to lead, what it takes to grow as a leader and what it takes to cultivate leadership in others (peers and superiors, as well as subordinates). 
As a developing country, women face obstacles and confront many shapes of sex-segregation in Saudi society and all that affect their efforts to get experience or knowledge as they have a limited number of opportunities to have work rather than a little chance to get leadership position. Consequently it is very hard to have long experience or big knowledge, especially if we know that Saudi women accounted for less than $1 \%$ of the private sector workforce in 2009. They were better represented within the government, where they made up $30 \%$ of employees in 2008 (DeAnne, 2011). And this was reflected on a 2010 World Economic Forum index of gender equality in 134 countries, whereas the six countries of the Gulf Cooperation Council (GCC) were all ranked below 100, ranging from 103 (UAE) to 129 (Saudi Arabia).

As a result of increasing enrolment of Saudi women in all levels of education and various fields of employment and aspects of public life in Saudi Arabia, the last 10 years witnessed a growing participation of women in senior management positions and in the decision-making process in public and private sectors. Recent developments indicate a clear strategic direction of policy makers and development plans in Saudi Arabia towards an even greater role for women in public life and into top leadership positions in public domains (Al-Ahmadi, 2011).

Of course, their opportunities to get experiences and knowledge in different fields of management are increasing along time especially nowadays with the increase trend towards encouragement of women to penetrate entrepreneurship world and the further involvement of them in workforce in order to increase their share in the Saudi economy, although there was no platform supporting young women in Saudi Arabia (Fatany, 2007).

Saudi women need to work in an environment that does not burden them with legal, social, and cultural constraints. Some women ask for flexible work policies which they consider critical in this regard, others ask for regulations that allow for part-time work, some women expressed their need to a quota for hiring females, similar to the Saudization quota (Note 1), others suggest that government have to create an institutional environment in which women can reach their full potential, as well as find the right combination of incentives and policies to keep individual women engaged, although most women agreed without exception that certain improvements in the work and social environment would be critical to fostering women's leadership in the region. Help them acquiring the experience and knowledge required for leadership positions will encourage women and ensure the possibility of female leadership, although it is clear that there is an institutional shift under way in women's economic participation (DeAnne et al., 2011).

According to OECD (2014), women lack the skills and knowledge necessary for them to have successful approach to banks for funding. This low level of financial literacy in women together with the perceptions on the complex process of application to get the loan from the bank represent barriers encountering women to succeed in obtaining the financial support they need to commence their business. Supporting women with the required training and information to facilitate their access to financial entities is essential to improve women entrepreneurship in MENA region.

Saudi Government exerts best endeavors to increase women employment in its seeking to help them to gain experiences. So in the year 2013, the Saudi Ministry of Labor issued a series of new directives such as: women no longer need their husband or custodian's permission to work, shops that cater exclusively to women, (i.e., lingerie, cosmetic and perfume shops) must only hire women, factories and supermarkets have been ordered to employ more women, and private and public businesses shall now create new jobs, separate spaces and facilities for women workers.

According to the literature review, Figure 1 provides a graphical view of the proposed women's leadership model.

The above suggested model shows the most important factors associated with a successful women leadership. In general education and continuous knowledge are essential factors that help any leader to succeed in his/her leading (AlShehabi, 1997). Experience which is combined by the leadership skills whether natural or acquired is found to be one of the very important elements in achieving the success of leadership. It is also found that the society's support, encouragement and level of social culture are the main and basic components that achieve the success of the Saudi Women leaders and sustain this kind of leadership as well (Badawi, 1997). 


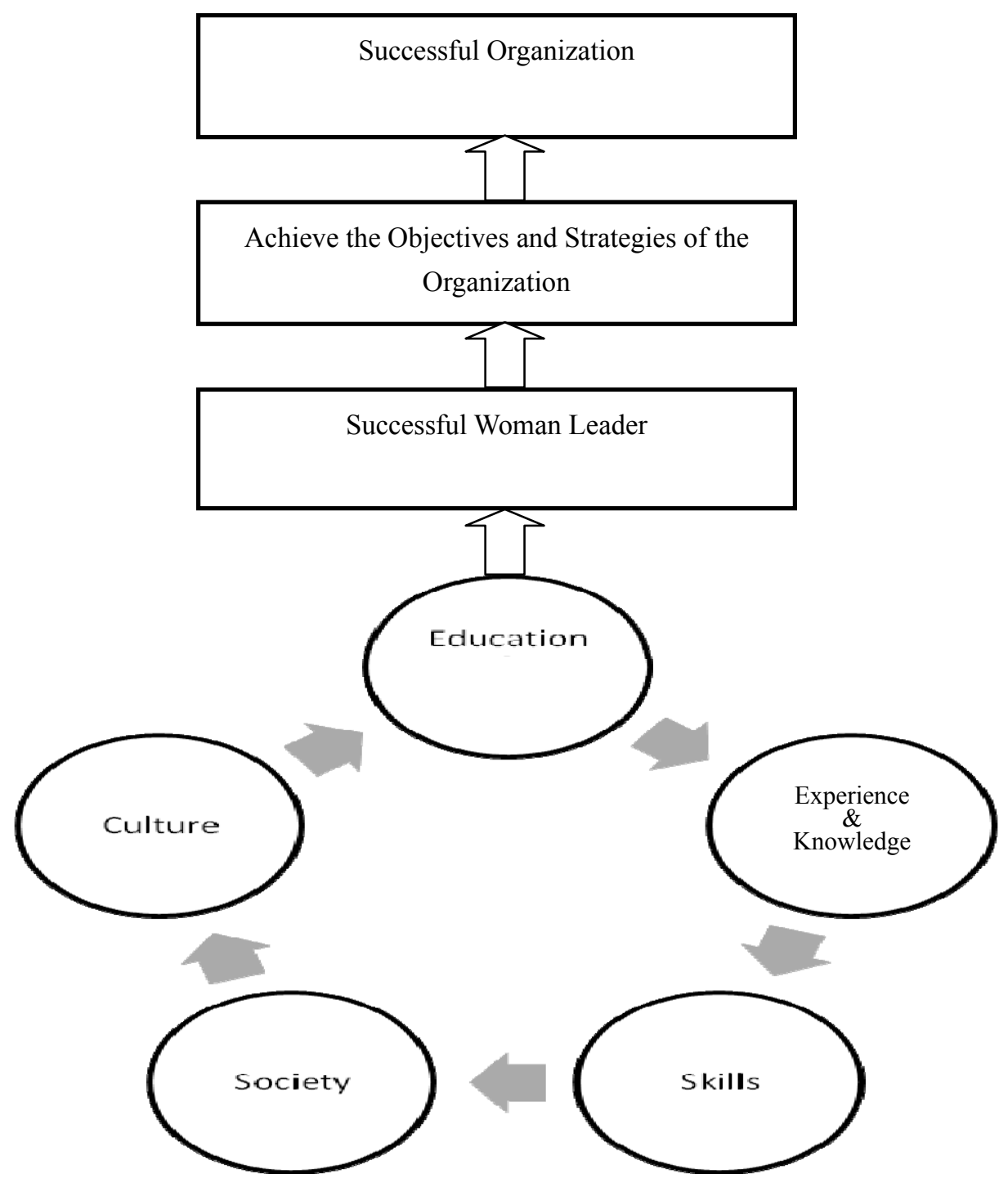

Figure 1. Women's leadership model

\section{Research Methodology and Hypotheses}

To test the validity of the postulated hypotheses $\left(\mathrm{H}_{\mathrm{i}}\right)$ against the sample information, the researchers specified (Figure 2) a Structural Equation Model (SEM).The model was estimated via Partial Least Squares (PLS) by using Smart PLS 3 Software (Ringle et al., 2015). A random sample of 37 Saudi women was used. Although sample size is relatively small, the researchers carried on with the investigation based on the following considerations: a) the number of Saudi women in top managing positions, although steadily increasing, is still limited, b) the, in the model estimated latent variables, follow a normal distribution, the same postulated for the population, therefore the sample is considered to be representative. The bootstrapping technique with 500 samples was used to estimate the significance of the weights (Efron \& Tibshirani, 1993). Smart PLS was chosen to estimate the model according to the following criteria: its algorithm converges in most cases achieving high statistical power even with reduced sample sizes, it is robust against missing data and it also presents prediction accuracy and non-data multi normality requirements (Henseler, Ringle, \& Sinkovics, 2009).

The main purpose of our research is to determine whether the factors proposed in women's leadership model (See Figure1), including Culture, Society, Skills, Experience and Knowledge and Education, explain the success of women leadership in Saudi Arabia.

Figure 2 shows the hypothesized model for measuring the impact of the five factors mentioned above on Saudi women leadership success. Below and on subsequent pages each hypothesis is described. 


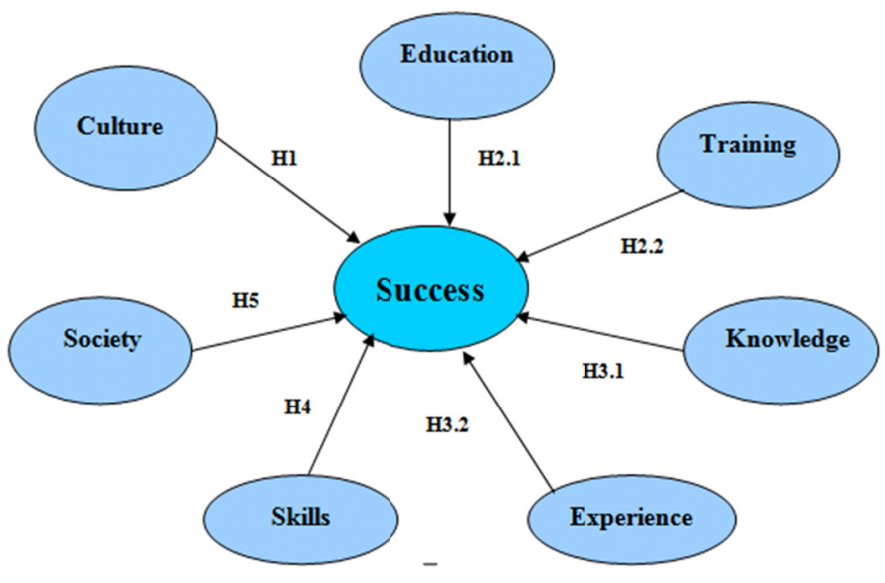

Figure 2. The proposed model and hypotheses

H1. The more culture encourages women to assume leading positions, the more success women can achieve.

Socio-cultural conditions and expectations, like values, customs and tastes have the major influence on organizations (Pearson, 2003). Globalization has brought a deep change in the economic and political environment and the necessity to manage diversity, offer a great change for women to occupy leadership positions despite perceptions of not being yet suitable for such positions (Evans, 2005). In many Muslim societies, women leadership role is very confined, whereas religion is interpreted differently within different societies, leading to gendered conceptualizations (Shah, 2010). Asmaa (2010) affirmed that Islamic Instructions (Sharia Laws) do not prohibit women leadership but people' culture in some developing countries has a negative impression about leader females despite the presence of many highly respected sample of women leaders in Islamic history. Therefore, the purpose of this hypothesis is to test if Saudi culture has an impact on women success as leaders. The success was measured as the position of women in organisations. We consider that the higher is the position of woman in an organization, the more successful she is as a leader. We also analysed if there are differences between generations regarding culture and if knowledge can explain less cultural barriers for women in leadership positions.

H2. The more education qualification women leaders have, the more success they may achieve

Saudi Arabia is considered as one of the Arab countries that encourage female education to compete the global market place especially in science and technology (Morgan, 2008). The majority of managers who are carrying different university certificates succeeded in their positions after obtaining some form of qualifications (Anderson \& Berdahl, 2005). Haymon et al., (1992) and Balcony (2006) have shown that there is a relationship between leadership style and educational achievement.

Leadership capabilities can also be obtained by training and acquiring of leadership skills. DeKlein (1997) supported that such skills can be acquired by excessive training and practice, which is measured as the starting point of building leadership personality. Hence in this hypothesis we have tested if higher education can play a role in the success of women leadership. Also, we have tested the relationship between training and success in leadership positions.

H3. Knowledge and experience have a positive impact on the success of women in leadership

Women can become more capable in achieving the organizational goals if they acquire deep knowledge (Laddin, 2007). According to Laddin (2007), such type of knowledge is critical in helping the leader women to think in a clear way about her role and function in the organization in order to support her success.

Keeny (2010) confirms that the great ability the Saudi women has in dealing with the internet and computer in the domain of knowledge production, has helped her in a significant way to overcome the obstacles stand against obtaining of the knowledge and experience required for leadership positions. So, in this hypothesis whether knowledge and experience have a positive impact on the success of Saudi women in leadership has been tested.

H4. The more skills the woman leader has, the most success she may achieve 
A study conducted by Whetten and Cameron (2010) has shown the link between skills and success. Caliper (2005) highlighted the distinguishing characteristics carried by women in terms of qualities of leadership when compared with men. His study indicates that women leaders are more assertive and persuasive, more empathetic and flexible, always acquire strong interpersonal skills, have a stronger need to getting the things done and are more willing to take risks than male leaders.

In the fourth hypothesis, the number of skills acquired by Saudi woman that can help her to achieve success in leadership positions have been analysed.

H5. The more society encourages women to assume leading positions, the more success women can achieve in their leadership

Hennig (2003) suggested that, despite the fact that the differences between women's and men's ability to carry out job responsibility are negligible whenever they carry the same job qualifications, the society is completely responsible of gender segregation. The many factors, including technology, liberalization tendency, information, communication revolution and modernization serve women and help them to call for their rights everywhere (Altintas \& Murat, 2008), but they do not have leadership positions as equal as man around the world yet (Calas \& Smircich, 1993).

The objective of the fifth hypothesis is to determine whether women that achieve success in their leadership positions are supported by the Saudi society.

\section{Results and Discussion}

Discriminant validity was evaluated according to the Fornell and Larcker criterion (Fornell \& Larcker 1981). Correlations between latent variables should be lower than the square root of the corresponding AVE. As it can be observed in the main diagonal of table 1, this is the case for the majority of the variables analyzed in the model, with the exception of the correlation between Society and Culture $(-0,87)$, which is higher than the square root of the corresponding $\operatorname{AVE}(0,73)$, and Training and Skills $(0,66$ vs. 0,63$)$.

Table 1. Latent variable correlations

\begin{tabular}{|c|c|c|c|c|c|c|c|c|c|}
\hline & Culture & Education & Experience & Knowledge & Skills & Society & Success & Training & Age \\
\hline Culture & 0,73 & & & & & & & & \\
\hline Education & $-0,41$ & 0,64 & & & & & & & \\
\hline Experience & $-0,56$ & 0,59 & 0,67 & & & & & & \\
\hline Knowledge & $-0,49$ & 0,24 & 0,49 & 0,81 & & & & & \\
\hline Skills & $-0,28$ & 0,44 & 0,46 & 0,35 & 0,63 & & & & \\
\hline Society & $-0,87$ & 0,50 & 0,58 & 0,47 & 0,16 & 0,66 & & & \\
\hline Success & 0,42 & $-0,45$ & $-0,65$ & $-0,46$ & $-0,37$ & $-0,52$ & 1,00 & & \\
\hline Training & $-0,49$ & 0,57 & 0,68 & 0,66 & 0,66 & 0,51 & $-0,48$ & 0,72 & \\
\hline Age & $-0,30$ & 0,13 & 0,58 & 0,18 & 0,26 & 0,16 & $-0,40$ & 0,24 & 1,00 \\
\hline
\end{tabular}

Internal consistency was measured by Composite Reliability and AVE (Table 2). Overall, the Composite Reliability takes values higher than the commonly admitted 0.5 threshold, with the exception of two variables, Skills (0.46) and Society $(0,02)$. AVE values for Culture, Knowledge, Success, Training and Age exceed the 0.5 value, as recommended by Fornell and Larcker (1981).

Table 2. Quality criteria overview

\begin{tabular}{cccccc}
\hline & AVE & Composite Reliability & R Square & Communality & Redundancy \\
\hline Culture & 0,54 & 0,60 & 0,29 & 0,54 & 0,11 \\
Education & 0,41 & 0,74 & & 0,41 & 0,10 \\
Experience & 0,45 & 0,79 & 0,65 & 0,45 & 0,08 \\
Knowledge & 0,66 & 0,80 & 0,44 & 0,66 & \\
Skills & 0,40 & 0,46 & & 0,40 & $-0,41$ \\
Society & 0,46 & 0,02 & 0,52 & 0,46 & 0,13 \\
Success & 1,00 & 1,00 & 0,32 & 1,00 & 0,20 \\
Training & 0,52 & 0,86 & & 0,52 & 1,00 \\
Age & 1,00 & 1,00 & & & 0,20 \\
\hline
\end{tabular}


The significance of the path coefficients was determined by the pseudo t-statistics. Path coefficients are significant if t-values exceed the 1.96 limit value ( $95 \%$ two tailed confidence interval). Overall, the relationship tested in the hypotheses did not have as result $\mathrm{t}$-values higher than 1.96 limit value. Only the relationship between Experience and Success $(\mathrm{t}=2.37 ; \mathrm{p}<0.05)$ met this condition, therefore H3 is partially validated. Statistically, the variables Culture, Education, Knowledge, Skills, Society and Training did not have a significant impact on the final variable measured, Success ( $t$ values $<1.96 ; \mathrm{p}>0.05$ ). But, the results show significant relations between some central variables such as: Education and Training $(\mathrm{t}=3.42 ; \mathrm{p}<0.05)$; Knowledge and Culture (3.00; $\mathrm{p}<0,05)$; Training and Experience $(\mathrm{t}=4.77 ; \mathrm{p}<0.05)$; Training and Knowledge $(\mathrm{t}=6.76 ; \mathrm{p}<0.05)$; Age and Experience $\mathrm{t}=3.68 ; \mathrm{p}<0.05$ ). Numerical values (decimal separator) should have a point. Not a comma, revise it.

Table 3. Total effects (Mean, STDEV, T-values, P-values)

\begin{tabular}{ccccccc}
\hline & $\begin{array}{c}\text { Original } \\
\text { Sample (O) }\end{array}$ & $\begin{array}{c}\text { Sample } \\
\text { Mean (M) }\end{array}$ & $\begin{array}{c}\text { Standard } \\
\text { Deviation } \\
\text { (STDEV) }\end{array}$ & $\begin{array}{c}\text { Standard } \\
\text { Error } \\
(\text { STERR) }\end{array}$ & $\begin{array}{c}\text { T Statistics } \\
(\mid \text { O/STERR) }\end{array}$ & $\begin{array}{c}\text { p-values } \\
\text { (two-tailed) }\end{array}$ \\
\hline Culture->Success & $-0,40$ & $-0,35$ & 0,33 & 0,33 & 1,21 & 0,234 \\
Education->Success & $-0,07$ & $-0,12$ & 0,22 & 0,22 & 0,33 & 0,743 \\
Education->Training & 0,57 & 0,61 & 0,17 & 0,17 & 3,42 & $0,001^{*}$ \\
Experience->Success & $-0,48$ & $-0,46$ & 0,20 & 0,20 & 2,37 & $0,023^{*}$ \\
Knowledge->CCulture & $-0,46$ & $-0,46$ & 0,15 & 0,15 & 3,00 & $0,005^{*}$ \\
Knowledge->Success & $-0,09$ & $-0,05$ & 0,26 & 0,26 & 0,33 & 0,743 \\
Skills->Success & $-0,26$ & $-0,12$ & 0,31 & 0,31 & 0,82 & 0,417 \\
Society->Success & $-0,56$ & $-0,03$ & 0,62 & 0,62 & 0,90 & 0,374 \\
Training->Experience & 0,57 & 0,59 & 0,12 & 0,12 & 4,77 & $0.000^{*}$ \\
Training->Knowledge & 0,66 & 0,66 & 0,10 & 0,10 & 6,76 & $0.000^{*}$ \\
Training->Success & $-0,01$ & $-0,03$ & 0,29 & 0,29 & 0,04 & 0.968 \\
Age->Culture & $-0,21$ & $-0,25$ & 0,16 & 0,16 & 1,38 & 0,176 \\
Age->Experience & 0,44 & 0,43 & 0,12 & 0,12 & 3,68 & $0,001^{*}$ \\
\hline
\end{tabular}

${ }^{*} \mathrm{p}<0,05$

Experience has a negative impact on success, with a path value of -0.48 . Although this result could be surprising, this could mean a shorter access time for the new woman generations to leadership. Results show that women, with high qualification, have received more training (H2) and have higher knowledge and experience (H3). The results also highlight the lack of experience of Saudi women in leading organizations.

A relationship between Knowledge and Culture (H1) and between Age and Experience (H3) has been identified. Knowledge has a negative impact on Culture (path value $=-0.46$ ). This means that knowledge can reduce access barriers for women in higher positions. The relationship between age and experience is positive (path value $=0.44$ ). This means that the knowledge that Saudi women leaders possess increases with the age.

\section{Conclusion}

Leadership success is found to have a positive impact on the success of organizations, where successful leaders can achieve organizational goals more efficiently and effectively. The presented model points out factors that promote the success of the leader, including education, skills, experience, society, culture and knowledge. Culture and society may represent an obstacle to the success of women in leadership like what happens in K.S.A., where Saudi women suffer from many forms of discrimination, that hamper their opportunity to get leadership positions, especially the traditional culture of Saudi society, which mixed with some Islamic practices embodied obstacles to women in Saudi Arabia to assume leadership positions. Furthermore, Saudi society with its special composition represents an obstacle to the success of women's leadership, while social mobility and Saudi culture currently on their way to modernity have seen many forms of change in favor of women's work and acceptance of her leadership.

Empirical results show that the leadership model does not explain the women leadership success in Saudi Arabia at this moment. Overall, the factors analyzed in the five hypotheses have not shown a significant impact on the final variable measured, leadership success of Saudi women. There is only one exception in the case of the 
variable Knowledge (H3), but even in this case the impact is negative. These results can be explained by the short access time of Saudi women in leadership positions. Also, our empirical study has shown that Saudi women with high studies also receive more training and present higher levels of knowledge and experience. Saudi Arabia has made important investments in the education of women in the last years and there is an important number of women who have the education and training for reaching leadership positions. The rate of Saudi women literacy has increased as it reaches $60 \%$ of students in higher education, and a very large number of them earned master and $\mathrm{PhD}$ degrees. But, as our study reveals, the country still does not fully exploits this potential.

We have also identified that knowledge has a negative effect on culture (H1). As the literature review revealed that in K.S.A, the culture represents an obstacle for women to get leadership positions, this could mean that cultural barriers could be greatly reduced through knowledge attainment.

Although the results of our research are important, the study has encountered several limitations. The major limitation of the study is the lack of literature conducted in the topic of women leadership as general and Saudi Arabia in particular. The uniqueness of the Saudi Society and culture in terms of adherence with legend traditions and customs complicated the positive findings which can be yielded in concern of culture and society. Western measures for culture and society have been considered. This may have affected our results. In further investigations other measures more oriented to K.S.A culture and society should be identified. Another limitation is that most of the participants of the interview are working on the educational field, a thing that reflected the lack of various opinions from other fields of leadership.

\section{References}

Abu-Nasr, D. (2013). Saudi women more educated than men are wasted resource.

Acker, J. (1992). From sex roles to gendered institutions. Contemporary Sociology: A Journal of Reviews, 565-569. http://dx.doi.org/10.2307/2075528

Aguirre, D., Master Cavanaugh, M., \& Sabbagh, K. (2011). LEADERSHIP STORIES-The Future of Women Leaders in the Middle East-A number of high-profile women are chipping at the" cement ceiling" in the Gulf countries and making it possible for others to do the same. Strategy and Business, (63), 68.

Ahmad, S. Z. (2011). Evidence of the characteristics of women entrepreneurs in the Kingdom of Saudi Arabia. International Journal of Gender and Entrepreneurship, 3(2), 123-143. http://dx.doi.org/10.1108/175662 61111140206

Al-Ahmadi, H. (2011). Challenges facing women leaders in Saudi Arabia. Human Resource Development International, 14, 149-166. http://dx.doi.org/10.1080/13678868.2011.558311

Al-Mohamed, A. (2010). Saudi women's rights: Stuck at a red light. Retrieved from http://www.arabinsight.org/ aiarticles/181.pdf. Retrieved 24 June 2010

Al-Shahabi, A. A. (1997). Problems face women in assuming leadership position: From women leaders view. Riyadh. Jareer Press

Altintas, F. Ç., \& Murat, H. (2008). The relationship between feminist/ womanist identity and leadership styles of women managers in Turkey, Gender in Management. An International Journal, 23(3), 175-193

Arvey, R. D., Rotundo, M., Johnson, W., Zhang, Z., \& McGue, M. (2006). The determinants of leadership role occupancy: Genetic and personality factors. The Leadership Quarterly, 17(1), 1-20. http://dx.doi.org/10. 1016/j.leaqua.2005.10.009

Australian Bureau of Statistics (ABS). (2006). Education and training experience. Australia 2005 (Data Cubes Only). Published: Wednesday 13 September 2006.

Badawi, F. (1997). Women leadership and continuous development. Arabic Studies Journal, 33.

Balcony, J. (2006). Education is key for women to overcome barriers in politics. Retrieved from http://mcminnala.com/pros-cons/education-is-key-for-women-to-overcome-barriers/

Berdahl, J. L., \& Anderson, C. (2005). Men, Women, and Leadership Centralization in Groups Over Time. Group Dynamics: Theory, Research, and Practice, 9(1), 45. http://dx.doi.org/10.1037/1089-2699.9.1.45

Berg, A. T., Hesdorffer, D. C., \& Zelko, F. A. (2011). Special education participation in children with epilepsy: what does it reflect? Epilepsy \& Behavior, 22(2), 336-341. http://dx.doi.org/10.1016/j.yebeh.2011.07.014

Calás, M. B., \& Smircich, L. (1993). Dangerous liaisons: The "feminine-in-management" meets "globalization". 
Business Horizons, 36(2), 71-81. http://dx.doi.org/10.1016/S0007-6813(05)80041-2

Caliper (2005). Women leaders study: The qualities that distinguish women leaders. At: Caliperonline.com.

Cheung, F. M., \& Halpern, D. F. (2010). Women at the top: powerful leaders define success as work+ family in a culture of gender. American Psychologist, 65(3), 182. http://dx.doi.org/10.1037/a0017309

DeKlein, K. (1997). How to be an effective leader (pp. 12-18). OMAF; Meg Penstone-OMAF.

Dilts, R. B. (1996). Visionary leadership skills: Creating a world to which people want to belong. Meta Pubns.

Eagly, A. H. (2007). Female leadership advantage and disadvantage: Resolving the contradictions. Psychology of women quarterly, 31(1), 1-12. http://dx.doi.org/10.1111/j.1471-6402.2007.00326.x

Eagly, A. H., Makhijani, M. G., \& Klonsky, B. G. (1992). Gender and the evaluation of leaders: A meta-analysis. Psychological bulletin, 111(1), 3. http://dx.doi.org/10.1037/0033-2909.111.1.3

Ecklund, E. H. (2006). Organizational culture and women's leadership: A study of six Catholic parishes. Sociology of religion, 67(1), 81-98. http://dx.doi.org/10.1093/socrel/67.1.81

Efron, B., \& Tibshirani, R. (1995). Cross-validation and the bootstrap: Estimating the error rate of a prediction rule. Division of Biostatistics, Stanford University.

Evans, D. (2005). Saudi Arabia to join WTO. USA Today. Retrieved December 3, 2005, from $\mathrm{http}: / / w w w . u s a t o d a y . c o m / m o n e y / w o r l d / 2005-10-26-s a u d i$ x.htm

Fatany, S. (2007). Saudi women: Towards a new era (1 st ed., p. 45). Ghaidaa for Publishing.

Fatany, S. (2013). The challenges facing Saudi women in the Shura council. Retrieved from http://english. alarabiya.net/views/2013/02/09/265229.html Gender Gap Report, 2009

Fornell, C., \& Larcker, D. F. (1981). Evaluating structural equation models with unobservable variables and measurement error. Journal of marketing research, 39-50. http://dx.doi.org/10.2307/3151312

García, P. M., \& de Pablos Heredero, C. (2014). Liderazgo Acomodaticio y Resultados Empresariales: Una Aproximación Desde El Análisis De Steve Jobs. Interciencia, 39(9), 673.

Greenleaf, R. K. (1970). The servant as leader. Management Journal.

Hausmann, R., Zahidi, S., Tyson, L., Hausmann, R., Schwab, K., \& Tyson, L. D. A. (2009). The global gender gap report 2009. World Economic Forum.

Hellum, A., \& Aasen, H. S. (Eds.). (2013). Women's Human Rights: CEDAW in International, Regional and National Law (Vol. 3). Cambridge University Press. http://dx.doi.org/10.1017/cbo9781139540841

Hennig, M. (2003). Africa's crises of governance: Civil society, leadership and the democratic process in Africa: What prospects? Retrieved from http://www.Sons of Africa

Henseler, J., Ringle, C. M., \& Sinkovics, R. R. (2009). The use of partial least squares path modeling in international marketing. Advances in International Marketing (AIM), 20, 277-320. http://dx.doi.org/10. 1108/S1474-7979(2009)0000020014

Hofstede, G. H., \& Hofstede, G. (2001). Culture's consequences: Comparing values, behaviors, institutions and organizations across nations. Sage.

http://he.moe.gov.sa/en/studyinside/universitiesStatistics/Pages/Students.aspx. Last Modified 26 Mar 2015 1:56 PM

Hughes, M., \& Zachariah, S. (2001). An Investigation into the Relationship Between Effective Administrative Leadership Styles and the use of Technology. IEJLL: International Electronic Journal for Leadership in Learning, 5(5). Jarnestrom

Idris, A. M. (2007). Cultural barriers to improved organizational performance in Saudi Arabia. SAM Advanced Management Journal, 72(2), 36.

Judge, T. A., Bono, J. E., Ilies, R., \& Gerhardt, M. W. (2002). Personality and leadership: a qualitative and quantitative review. Journal of applied psychology, 87(4), 765. http://dx.doi.org/10.1037/0021-9010.87.4. 765

Keeny, A. A. (2010). Arab women's leadership in cultural and knowledge production. Retrieved from http://EzineArticles.com/?expert=Keeny_A_Ali

Kickul, J., \& Neuman, G. (2000). Emergent leadership behaviors: The function of personality and cognitive 
ability in determining teamwork performance and KSAs. Journal of Business and Psychology, 15(1), 27-51. http://dx.doi.org/10.1023/A:1007714801558

Koenig, M. A., Ahmed, S., Hossain, M. B., \& Mozumder, A. K. A. (2003). Women's status and domestic violence in rural Bangladesh: individual-and community-level effects. Demography, 40(2), 269-288. http://dx.doi.org/10.1353/dem.2003.0014

Laddin, M. (2007). The leadership experience: Manager information. Retrieved from http://www.ecologyand society.org/vol9/iss2/art5/

Lord, R. G., De Vader, C. L., \& Alliger, G. M. (1986). A meta-analysis of the relation between personality traits and leadership perceptions: An application of validity generalization procedures. Journal of Applied Psychology, 71(3), 402. http://dx.doi.org/10.1037/0021-9010.71.3.402

Lowen, L. (2011). Qualities of women leaders: The unique leadership characteristics of women. Retrieved from http://books.google.com.sa/books

Mario, P. (2009). Promoting gender equality to prevent violence against women. WTO Publications.

Miller, B. (2011). Education, knowledge sharing between project teams and its cultural antecedents. Journal of Knowledge Management, 16(3), 435-447. http://dx.doi.org/10.1108/13673271211238751

Moghadam, V. M. (2003). Modernizing women: Gender and social change in the Middle East. Lynne Rienner Publishers.

Morgan, T. (2008). Saudi Arabia: More female graduates but no more jobs.

Nestor, R. (2013). Updates- leadership in Saudi Arabia: Women's perspective. Retrieved from http://lfheblog.com/2013/09/12/leadership-in-saudi-arabia-womens-perspective/

Nisaar, N. D. (2010). Academic qualifications are commonly felt to give a person the best chance of success in life. How far is this true? Retrieved January 14, 2010, from http://www.idebate.org/debatabase/topic_details. php?topicID $=885$

Norris, P., \& Inglehart, R. (2000, May). Cultural barriers to women's leadership: A worldwide comparison. Management Journal.

OECD. (2014). Women in business 2014: Accelerating entrepreneurship in the Middle East and North Africa Region. OECD Publishing

Okaz Newspaper. (2011, September 26). Saudi king: Women will be allowed to vote and run for office. PBS.

Okaz Newspaper. Saturday 24/9/2011. Vol.: 15624

Organizational culture and environment: The constraints. In Dimensions of Organizational Culture (Chapter-3 (Exhibit 3.2) 3.7). Pearson Education Canada Inc.

Ravasi, D., \& Schultz, M. (2006). Responding to organizational identity threats: Exploring the role of organizational culture. Academy of Management Journal, 49(3), 433-458. http://dx.doi.org/10.5465/AMJ. 2006.21794663

Ringle, C. M., Wende, S., \& Becker, J. M. (2014). SmartPLS 3. SmartPLS, Hamburg.

Sabattini, L. (1999). Retrieved from http://Top7Business.com/?expert=LauraSabattini, Credit Research Foundation.

Shah, S. J. (2010). Re - thinking educational leadership: exploring the impact of cultural and belief systems. International Journal of Leadership in Education, 13(1), 27-44. http://dx.doi.org/10.1080/1360312 0903244879

Similes Dictionary. (1988). (1st ed.). C) The Gale Group, Inc.

Souad, Ahmad, M., Al-Omari. (2007). Leadership in Saudi Arabia, Riyadh (P3). King Saud University Press.

The American Heritage ${ }^{\circledR}$ Dictionary of the English Language. Fourth Edition Copyright $@ 2000$ by Houghton Mifflin Company. Updated in 2009. Published by Houghton Mifflin Company.

Webster, R. D. (1989). Organizational culture. The Journal of Marketing, 53(1), 3-15.

Westbrook, P. (2009). The Relationship between the Educational Qualifications of Chief Financial Officers and the Effectiveness of Local District Financial Leadership in Alabama Public Schools: A Policy Analysis. Academic Leadership Journal, 7(3), 94-99. 
Whetten, D. A., \& Cameron, K. S. (2010). Developing Management Skills.

Zaccaro, S. J. (2007). Trait-based perspectives of leadership. American Psychologist, $62(1), 6$. http://dx.doi.org/10.1037/0003-066X.62.1.6

\section{Note}

Note 1. Saudization quota: which requires that a certain percentage of employees in any company operating in Saudi Arabia be Saudi nationals

\section{Copyrights}

Copyright for this article is retained by the author(s), with first publication rights granted to the journal.

This is an open-access article distributed under the terms and conditions of the Creative Commons Attribution license (http://creativecommons.org/licenses/by/3.0/). 